JURNAL CEMERLANG: Pengabdian pada Masyarakat ISSN 2654-4741

Vol. 1, No. 1, 2018, $58-70$

DOI: https://doi.org/10.31540/jpm.v1i1.159

\title{
PELATIHAN GOOGLE CLASSROOM UNTUK MENGOPTIMALISASI \\ PROSES PEMBELAJARAN DI FKIP UNIVERSITAS TAMANSISWA \\ PALEMBANG
}

Malalina, Rika Firma Yenni

Universitas Tamansiswa Palembang, Indonesia

\begin{abstract}
ABSTRAK
Kemajuan teknologi Indonesia berkembang sangat pesat setiap tahunnya. Kemajuan teknologi tidak bisa dihindari dan berpengaruh secara tidak langsung dalam bidang pendidikan. Kemajuan teknologi dibidang Pendidikan yaitu penggunaan smartphone dalam pembelajaran. Salah satu media online yang dapat digunakan dalam proses pembelajaran adalah googleclassroom. Tujuan dalam kegiatan pengabdian masayarakat adalah untuk memberikan pengetahun bagaimana cara membuat google classroom dan melatih peserta menggunakan google classroom dalam proses pembelajaran. Masalah dalam kegiatan ini adalah dosen belum memanfaatkan aplikasi pembelajaran secara online yaitu google classroom untuk optimalisasi dalam proses pembelajaran. Selain itu, waktu proses pembelajaran yang dipergunakan dalam kurang optimal. Metode dalam kegiatan pengabdian ini adalah ceramah, diskusi dan praktek langsung dengan simpulan peserta sudah dapat membuat dan menggunakan fitur-fitur yang ada pada google classroomdalam proses pembelajara serta adanya media pembelajaran google classroomdalam setiap mata kuliah yang diampu oleh setiap peserta dalam proses pembelajaran di FKIP Universitas Tamansiswa Palembang.
\end{abstract}

KEYWORDS

Teknologi, google classroom, pembelajaran online
ARTICLE HISTORY

Received 23 November 2018

Revised 8 December 2018

Accepted 12 December 2018

CORRESPONDENCE Malalina@malalina@unitaspalembang.ac.id 


\section{JURNAL CEMERLANG: Pengabdian pada Masyarakat}

ISSN 2654-4741

Vol. 1, No. 1, 2018, $58-70$

DOI: https://doi.org/10.31540/jpm.v1i1.159

PENDAHULUAN

Kemajuan teknologi Indonesia berkembang sangat pesat setiap tahunnya. Kemajuan teknologi tidak bisa dihindari dan berpengaruh secara tidak langsung dalam segala bidang baik dalam bidang ekonomi, politik, dan juga dalam bidang pendidikan. Herrington (2008) pemanfaatan teknologi dapat digunakan sebagai media pembelajaran yang dapat diakses kapan saja dan dimana saja menggunakan media portabel seperti smartphone. Menurut kamus oxford dictionaries smartphone adalah sebuah ponsel yang mampu untuk melakukan banyak fungsifungsi komputer, biasanya mempunyai layar yang relatif besar dan sistem operasi yang mampu untuk menjalankan aplikasi-aplikasi umum. Smartphone dapat menjadi sarana Penguatan Pendidikan Karakter (PPK) siswa, akan tetapi dibutuhkan pendampingan ekstra baik dari guru maupun orangtua (Ningsih, 2018). Kitchenham (2011) berpendapat pemanfaatan smartphone dalam program pendidikan menjadikan perangkat ini sebagai salah satu bentuk perangkat yang dapat digunakan sebagai alternatif dalam pengembangan media. Sehingga Pemanfaatan smartphone dalam pembelajaran yaitu dengan menerapkan proses komunikasi yang terdiri dari materi pembelajaran yang dikirim oleh guru kepada siswa dengan media pembelajaran online.

Pembelajaran online adalah bagian dari pembelajaran berbasis teknologi yang memanfaatkan sumber daya internet, intranet, dan extranet (Permana, 2009). Menurut Waryanto (2006) keuntungan pembelajaran online adalah dapat digunakan untuk menyampaikan pembelajaran tanpa dibatasi ruang dan waktu, dapat menggunakan berbagai sumber yang sudah tersedia di internet, bahan ajar relatif mudah untuk diperbaharui. Selain itu, dapat untuk lebih meningkatkan kemandirian siswa dalam melakukan proses pembelajaran.

Salah satu media pembelajaran yang dapat digunakan secara online adalah google classroom. Google classroom dapat diakses melalui komputer atau smartphone sehingga memudahkan penggunanya. Iftakhar (2016) google classroom efektif dalam memahami dan mengevaluasi persepsi guru dan siswa dalam proses pengajaran dan pembelajaran berkualitas. Selain itu, Wicaksono dan 


\section{JURNAL CEMERLANG: Pengabdian pada Masyarakat}

\section{ISSN 2654-4741}

Vol. 1, No. 1, 2018, 58 - 70

DOI: https://doi.org/10.31540/jpm.v1i1.159

Rachmadyanti (2017), penggunaan google classroom dapat memberikan akses terhadap siswa dalam melakukan pembelajaran secara daring. Guru dapat memberikan pembelajaran meskipun tidak di dalam kelas. Izenstark dan Leahy (2015), desain dari google classroom sudah tidak asing lagi bagi siswa-siswa karena mereka sudah menggunakan beberapa produk dari google via akun google apps.

Manfaat google classroomadalah membuat sederhana pengelolaan tugas, meningkatkan kolaborasi, dan meningkatkan komunikasi yang lebih baik, sehingga dalam proses pembelajaran akan menjadi lebih bernilai dan bermanfaat; seorang tenaga pendidik dapat membuat suatu kelas dalam google classroom, membagikan tugas, mengirimkan saran, dan melihat kegiatan proses pembelajaran di satu tempat dengan cepat, mudah dan tanpa kertas.; Dilengkapi dengan teknologi keamanan terbaik tanpa biaya tambahan; google classroom dapat diakses oleh dosentidak membutuhkan waktu yang lama. Dengan googleclassroom, dosen dapat mengelola tugas serta berhubungandengan siswa dan walinya dalam pembelajaran di satu tempat yang praktis; Selain itu juga, dosen dapat memberikan saran secara langsung dan memeriksa perkembangan hasil belajar siswa sehingga dapat meningkatkan prestasi siswa. Google classroom juga dapat menyesuaikan waktu dosen sehingga dapat fokus melakukan tugasnya, yaitu mengajar.

Wikipedia (2017) Fitur-fitur yang dimiliki oleh google classroom adalah :

\section{Assigmenments (tugas)}

Penugasan disimpan dan dinilai pada rangkaian aplikasi produktivitas google yang memungkinkan kolaborasi antara guru dengan siswa atau siswa kepada siswa. Dokumen yang ada di googledrive siswa dengan guru, file di-host di drive siswa dan kemudian diserahkan untuk penilaian. Guru dapat memilih file yang kemudian dapat diperlakukan sebagai template sehingga setiap siswa dapat mengedit salinannya sendiri dan kemudian kembali ke nilai kelas alih-alih membiarkan semua siswa melihat, menyalin, atau mengedit dokumen yang sama. Siswa juga dapat menentukan untuk melampirkan 


\section{JURNAL CEMERLANG: Pengabdian pada Masyarakat}

ISSN 2654-4741

Vol. 1, No. 1, 2018, $58-70$

DOI: https://doi.org/10.31540/jpm.v1i1.159

dokumen tambahan dari drive mereka ke tugas.

2. Grading (pengukuran)

Google classroom mendukung banyak skema penilaian yang berbeda. Guru memiliki pilihan untuk melampirkan file ke tugas dimana siswa dapat melihat, mengedit, atau mendapatkan salinan individual. Siswa dapat membuat file dan kemudian menempelkannya ke tugas jika salinan file tidak dibuat oleh guru. Guru memiliki pilihan untuk memantau kemajuan setiap siswa pada tugas di mana mereka dapat memberi komentar dan edit. Berbalik tugas dapat dinilai oleh guru dan dikembalikan dengan komentar agar siswa dapat merevisi tugas dan masuk kembali. Setelah dinilai, tugas hanya dapat diedit oleh guru kecuali jika guru mengembalikan tugas masuk.

3. Communication (komunikasi)

Pengumuman dapat diposkan oleh guru ke arus kelas yang dapat dikomentari oleh siswa yang dapat memungkinkan komunikasi dari dua arah yaitu antara guru dan siswa. Siswa juga dapat memposting ke aliran kelas tapi tidak akan setinggi prioritas sebagai pengumuman oleh seorang guru dan dapat dimoderasi. Beberapa jenis media dari produk google seperti file video youtube dan google drive dapat dilampirkan ke pengumuman dan pos untuk berbagi konten. Gmail juga menyediakan pilihan email bagi guru untuk membagikan email ke satu atau lebih siswa di antarmuka google classroom. Google classroom dapat diakses di website atau melalui seluler Android dan iOSClassroom.

4. Time-Cost (hemat waktu)

Guru dapat menambahkan siswa dengan memberi siswa kode untuk mengikuti kelas. Guru yang mengelola beberapa kelas dapat menggunakan pengumuman yang telah diumumkan di kelas lain berupa tugas atau pertanyaan. Guru juga dapat berbagi tulisan di beberapa kelas dan juga kelas arsip untuk kelas masa depan. Pekerjaan siswa, tugas, pertanyaan, nilai, komentar semua dapat diatur oleh satu atau semua kelas, atau diurutkan menurut apa yang perlu dikaji.

https://ojs.stkippgri-lubuklinggau.ac.id/index.php/JPM 


\section{JURNAL CEMERLANG: Pengabdian pada Masyarakat}

\section{ISSN 2654-4741}

Vol. 1, No. 1, 2018, $58-70$

DOI: https://doi.org/10.31540/jpm.v1i1.159

\section{Archive Course (arsip program)}

Kelas memungkinkan instruktur untuk mengarsipkan kursus pada akhir masa jabatan atau tahun. Saat kursus diarsipkan, situs tersebut dihapus dari beranda dan ditempatkan di area Kelas Arsip untuk membantu guru mempertahankan kelas mereka saat ini. Ketika kursus diarsipkan, guru dan siswa dapat melihatnya, namun tidak dapat melakukan perubahan apapun sampai dipulihkan.

\section{Mobile Application (aplikasi dalam telepon genggam)}

Aplikasi seluler googleclassroom, yang diperkenalkan pada bulan Januari 2015, tersedia untuk perangkat iOS dan android. Aplikasi membiarkan pengguna mengambil foto dan menempelkannya ke tugas mereka, berbagi file dari aplikasi lain, dan mendukung akses offline.

\section{Privacy (privasi)}

Berbeda dengan layanan konsumen google, google classroom, sebagai bagian dari $G$ Suite for Education, tidak menampilkan iklan apa pun dalam antarmuka untuk siswa, fakultas, dan guru, dan data pengguna tidak dipindai atau digunakan untuk tujuan periklanan

Google classroom mempunyai banyak manfaat untuk pembelajaran tetapi belum banyak dosen di FKIP Universitas Tamansiswa yang memahami dan menggunakannya. Oleh karena itu perlu adanya kegiatan pengabdian "Pelatihan Google Classroom untuk Mengoptimalisasi Proses Pembelajaran di FKIP Universitas Tamansiswa Palembang”. Tujuan pelatihan ini adalah memberikan pengetahuan bagaimana cara membuat google classroom dan melatih peserta menggunakan google classroom untuk mengoptimalkan waktu proses pembelajaran.

\section{MASALAH}

Berdasarkan uraian di atas dapat dirumuskan masalah yang berkaitan dengan kegiatan pengabdian ini yaitu dosen belum memanfaatkan aplikasi pembelajaran secara online yaitu google classroom untuk optimalisasi dalam https://ojs.stkippgri-lubuklinggau.ac.id/index.php/JPM 


\section{JURNAL CEMERLANG: Pengabdian pada Masyarakat}

ISSN 2654-4741

Vol. 1, No. 1, 2018, $58-70$

DOI: https://doi.org/10.31540/jpm.v1i1.159

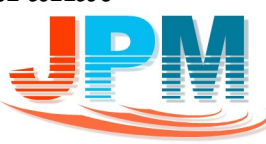

proses pembelajaran. Selain itu, waktu proses pembelajaran yang dipergunakan dirasakurang optimal.

\section{METODE PELAKSANAAN}

Untuk mengatasi permasalahan dosen yang belum dapat memanfaatkan googleclassroombaik maka dilakukan pelatihan google classroom di FKIP Universitas Tamansiswa palembang. Metode yang digunakan dalam kegiatan pengabdian ini berupa pelatihan yang lebih banyak pada praktek langsung dengan membat google classroom pada matakuliah yang didapatkan oleh dosen. Selain itu, digunakan juga metode ceramah dan diskusi. Metode ceramah dan diskusi digunakan untuk menyampaikan informasi yang berkaitan dengan google classroom, teori-teori tentang google classroom, serta manfaat menerapkan google classroom. Selama kegiatan peserta akan mendapatkan modul tentang penggunaan google classroom. Metode bimbingan dan praktek langsung digunakan untuk menindaklanjuti dan mematangkan materi yang telah disampaikan dalam ceramah dan diskusi.Lokasi Pelatihan ini dilaksanakan di FKIP Universitas Tamansiswa Palembang pada tanggal 5 Oktober 2018 durasi kegiatan pengabdian ini 420 menit dengan melibatkan dosen dari FKIP Universitas Tamansiswa Program Studi Pendidikan Matematika dan pendidikan Bahasa Inggris. Peserta dalam pelatihan ini terdiri dari dosen tetap dan dosen luar biasa dengan jumlah 20 peserta.

\section{HASIL DAN PEMBAHASAN}

Kegiatan pelaksanaan pengabdian kepada masyarakat terdiri dari persiapan, pelaksanaan pengabdian dan hasil kegiatan.

\section{Persiapan}

Persiapan dalam kegiatan pengabdian masyarakat meliputi berkoordinasi dengan pimpinan fakultas tentang penggunaan google classroom dalam proses pembelajaran, menyebarkan undangan melalui grup whatsapp Dosen FKIP Universitas Tamansiswa Palembang, menyaipkan materi, ruangan serta alat-alat yang digunakan dalam pelaksanaan kegiatan. 
JURNAL CEMERLANG: Pengabdian pada Masyarakat ISSN 2654-4741

Vol. 1, No. 1, 2018, $58-70$

DOI: https://doi.org/10.31540/jpm.vli1.159

2. Pelaksanaan

Penyampaian materigoogle classroom terdiri dari pembuatan google classroom.

\section{Akun Gmail}

Pengguna harus mempunyai akun gmail yang aktif kemudian pengguna masuk google dengan menggunakan akun email yang aktif.

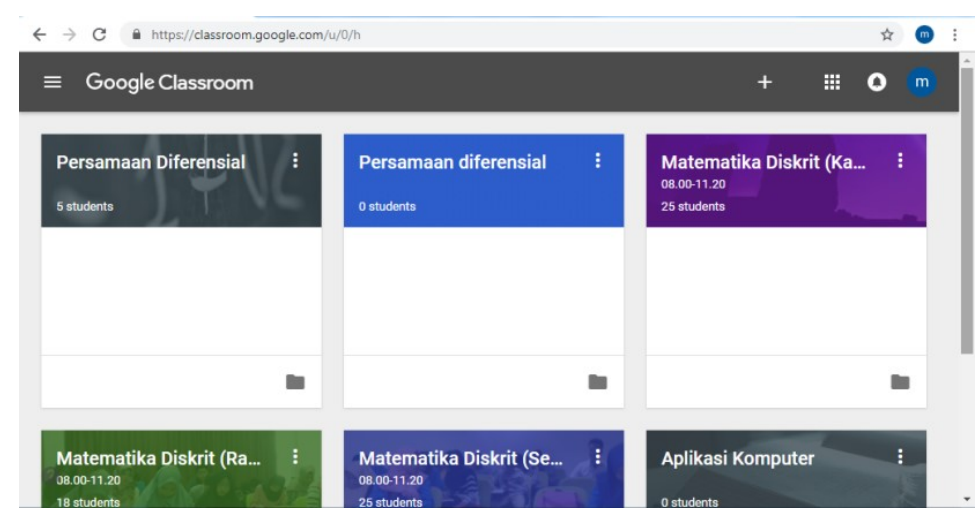

Gambar 1. Tampilan google classroom

Untuk membuat kelas, klik tanda “+” terlihat pada gambar berikut ini

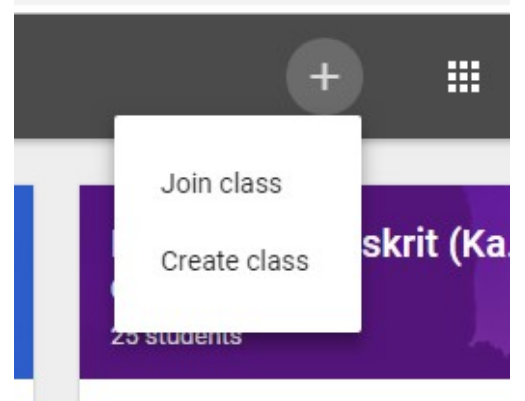

\section{Gambar 2. Tampilan gabung kelas atau membuat kelas}

Create Class digunakan oleh dosen untuk membuat kelas baru yang akan diajarkan selama satu semester sedangkan Join Class digunakan oleh mahasiswa untuk bergabung dalam suatu kelas yang akan diikutinya selama satu semester dengan menggunakan kode yang telah diberikan oleh dosen.

Pilih Create class, dan setelah itu berikan nama kelas yang akan diampu selama satu semester. Klik pada kotak I've read and understand the above https://ojs.stkippgri-lubuklinggau.ac.id/index.php/JPM 
JURNAL CEMERLANG: Pengabdian pada Masyarakat ISSN 2654-4741

Vol. 1, No. 1, 2018, $58-70$

DOI: https://doi.org/10.31540/jpm.v1i1.159

notice, and I'm not using Classroom at a school with students Kemudian Klik Continue.

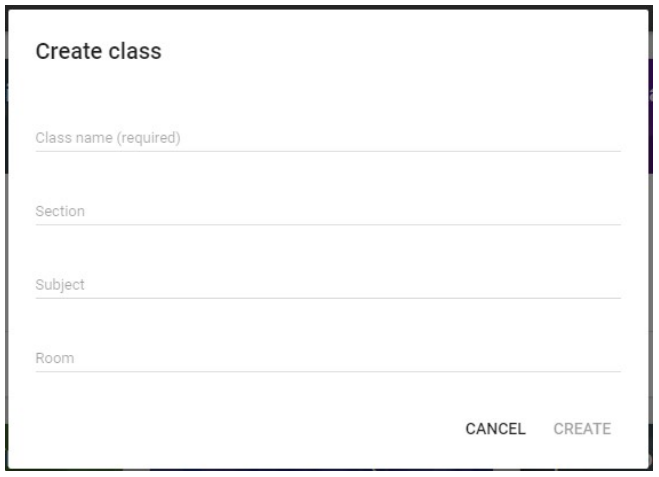

Gambar 3. Informasi kelas

Isilah nama kelas yang akan diampu selama satu semester dan keterangan lainnya untuk menjelaskan kelas yang akan diampu. Jika sudah selesai diisi seilahkan klik Create.

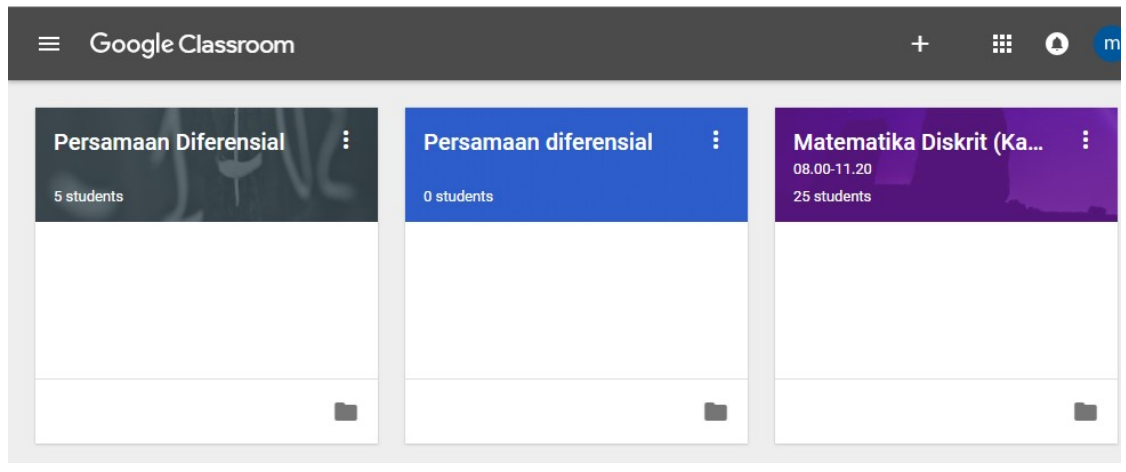

Gambar 4. Tampilan google classrom dengan beberapa kelas

\begin{abstract}
Material kelas dapat ditambahkan berupa file-file seperti silabus, rencana pembelajaran, tata tertib kelas, kontrak kuliah, materi, link ke sumber informasi lain, dan sebagainya. Untuk menambahkan materi dilakukan dengan cara Klik "Add class materials..." Beri keterangan judul materi kemudian upload materi dari komputer atau dari google drive, youtube, maupun link ke laman web yang lain.
\end{abstract}


JURNAL CEMERLANG: Pengabdian pada Masyarakat ISSN 2654-4741

Vol. 1, No. 1, 2018, $58-70$

DOI: https://doi.org/10.31540/jpm.v1i1.159

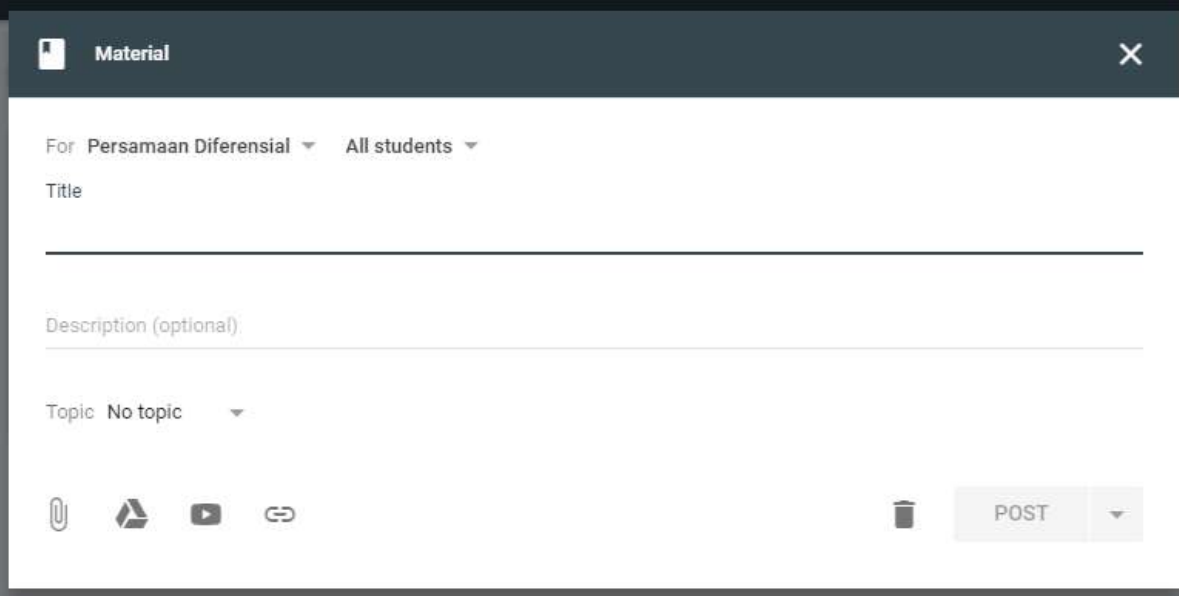

Gambar 5. Menambahkan material kelas

Menambah Mahasiswa dapat dilakukan dengan menggunakan kode kelas. Pada saat membuat kelas baru, google classroom akan memberikan kode kelas yang dapat digunakan oleh mahasiswa untuk dapat bergabung masuk kedalam kelas yang akan dipelajari selama satu semester. Kode google classroom dari 7 digit unik. Kode yang diberikan oleh google classroombisa direset atau diganti, dan dinonaktifkan apabila tidak ingin ada orang lain yang bukan mahasiswa dalam kelas itu untuk bergangung kedalam kelas. Langkahlangkah mahsiswa untuk Join ke dalam kelas yang telah dibuat adalah dengan memberikan kode kelas ke mahasiswa.

\section{Persamaan Diferensial}

\footnotetext{
General

Class code

Stream

Show deleted items

Only teachers can view deleted items.
}

Students can post and comment

n87zkf $~-$

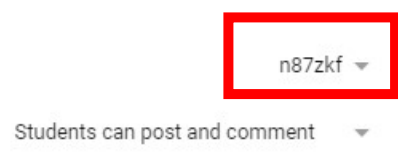

Gambar 6. Kode Unik Kelas 
JURNAL CEMERLANG: Pengabdian pada Masyarakat ISSN 2654-4741

Vol. 1, No. 1, 2018, $58-70$

DOI: https://doi.org/10.31540/jpm.v1i1.159

Dalam google classroom bisa memberikan pengumuman kepada mahasiswa di manapun dan kapapunpun. Bagian pengumuman ada pada bagian stream . Streamdigunakan oleh Dosenuntuk melihat dan menambahkan pengumuman, tugas, topik diskusi, dan komentar kepada mahasiswa.

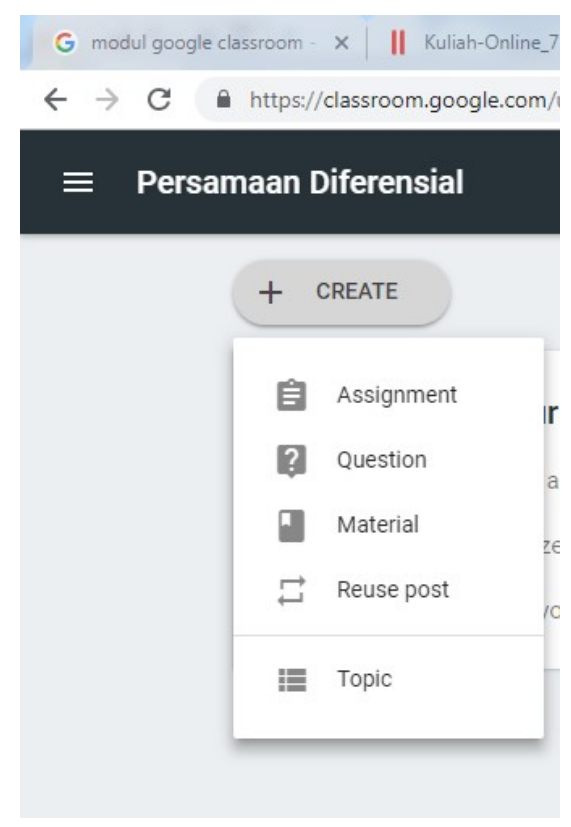

\section{Gambar 7. Membuat pengumuman, tugas, diskusi dan materi}

a. Announcement (pengumuman) adalah cara yang baik untuk berkomunikasi kepada mahasiswa, berbagi informasi, pengingat batas akhir pengumpulan tugas.

b. Assignment tugas digital yang diberikan dosendengan batas waktu tanggal, jam dan pengumpulan tugas dalam bentuk file.

c. Question (diskusi) adalah pertanyaan yang diberikan oleh dosen berupa jawaban singkat atau pilihan ganda untukmahasiswa agar dihadikan bahan diskusi.

d. Reuse post menggunakan kembali pengumuman, tugas atau pertanyaan yang telah diumumkan di kelas sebelumnya diumumkan kembali di kelas yang berbeda. (untuk menghemat waktu) 
JURNAL CEMERLANG: Pengabdian pada Masyarakat ISSN 2654-4741

Vol. 1, No. 1, 2018, $58-70$

DOI: https://doi.org/10.31540/jpm.v1i1.159

Setelah pelaksanaan pelatihan selesai selanjutnya adalah proses tanya jawab pertanyaan lebih kepada masalah pengoperasian google classroompada laptop dan smartphone. Pemateri menjawab pertanyaan dengan langsung mendatangi peserta dan membantu mengoperasikan pada laptop atau smartphonepeserta. Peserta sangat antusias selama pelaksanaan kegiatan pengabdian ini. Antusias peserta selama kegiatan berlangsung terlihat dari :

a. Peserta berpartisipasi aktif dalam setiap tahapan kegiatan dan langsung bertanya jika mengalami kesulitan dalam pembuatangoogle classroom.

b. Setiap peserta telah memiliki aplikasi pembeljaran online yaitu google classroom yang akan digunakan dalam proses pembelajaran.

3. Hasil Kegiatan

Setelah dilakukan persiapan dan pelaksanaan kegiatan pengabdian, hasil yang didapatkan peserta yang mengikuti kegiatan ini adalah :

a. Dosen mempunyai aplikasi pembelajaran online yatu google classroom secara gratis.

b. Dosen mempunyai google classroom dengan beberapa mata kuliah sehingga memperlancar komunikasi antara dosen dan mahasiswa.

c. Dosen dapat mengirimkan materi yang akan pelajari tugas kepada mahasiswa sehingga waktu yang digunakan dalam proses pembelajaran akan dapat optimal.
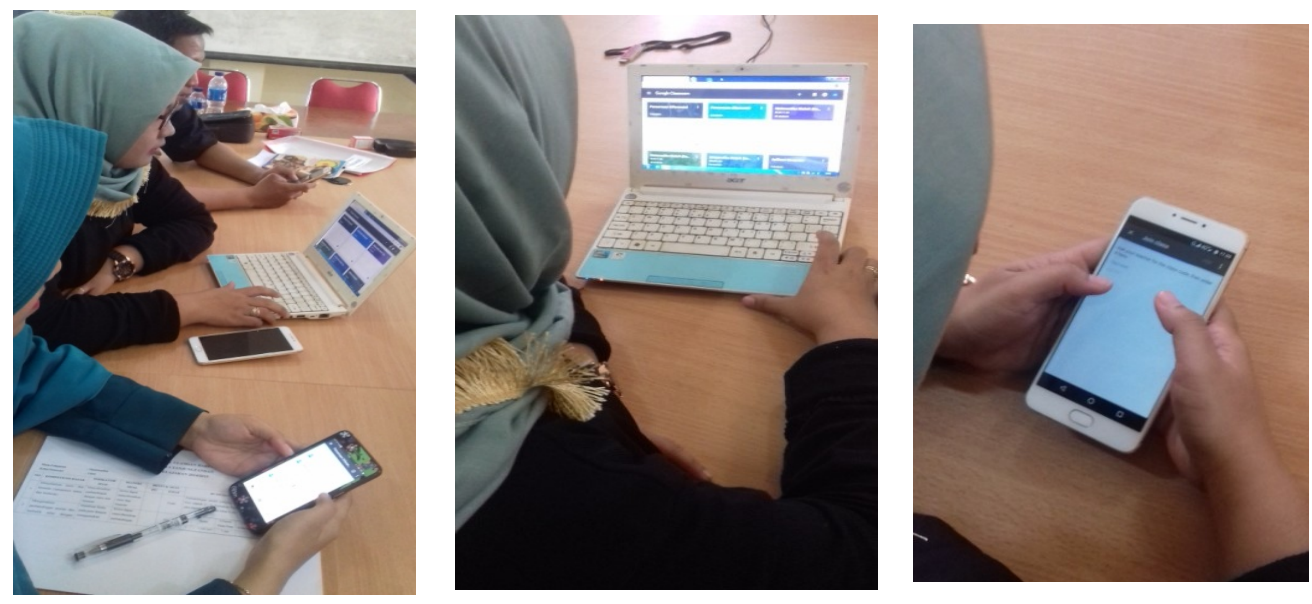

Gambar 8.Google classroom yang telah dimiliki Dosen

https://ojs.stkippgri-lubuklinggau.ac.id/index.php/JPM 


\section{JURNAL CEMERLANG: Pengabdian pada Masyarakat}

ISSN 2654-4741

Vol. 1, No. 1, 2018, $58-70$

DOI: https://doi.org/10.31540/jpm.v1i1.159

\section{SIMPULAN}

Dari keseluruhan pelaksanaan pelatihan terlihat hasil yang baik, dengan simpulan:

1. Peserta sudah dapat membuat google classroom yang dapat digunakan dalam proses pembelajaran dan peserta sudah bisa menggunakan fitur-fitur yang ada di google classroom dalam proses pembelajaran di FKIP Universitas Tamansiswa Palembang.

2. Peserta mempunyai media pembelajaran google classroom dalam setiap mata kuliah yang diampu oleh setiap peserta dalam proses pembelajaran di FKIP Universitas Tamansiswa Palembang.

\section{DAFTAR PUSTAKA}

Anonim. 2018. Oxford DictionariesOnline. (https://www.oxforddictionaries.com/)

Herrington, A. (2008). Adult educators" authentic use of smartphones to create digital teaching resources. In R. Atkinson \& C. McBeath (Eds.), Annual Conference of the Australasian Society for Computers in Learning in Tertiary Education (pp. 414-418). Melbourne, Australia: Deakin University. ( https://ro.uow.edu.au/cgi/viewcontent.cgi?referer=https://www.google.co.id/\&http sredir $=1 \&$ article $=2009 \&$ context $=$ edupapers)

Iftakhar, Shampa. (2016). Google Classroom: What Works and How?. Journal of Education and Social Sciences, 3 (feb), 12-18. (http://jesoc.com/wpcontent/uploads/2016/03/KC3 35.pdf)

Izenstark, Amanda, and Katie L. Leahy. 2015. "Google Classroom for Librarians: Features and Opportunities." Library Hi Tech News 32 (9):1-3. https://doi.org/10.1108/LHTN-05-2015-0039.

Kitchenham, A. (2011). Models for interdisciplinary mobile learning: delivering information to students. Hersey PA: IGI Global.

Ningsih, Sri. (2018). Smartphone dalam Pembelajaran dan PPK. Jateng pos (http://jatengpos.co.id/smartphone-dalam-pembelajaran-dan-ppk)

Permana, Pepen. (2009). E-Learning, Sistem Manajemen Pembelajaran Online. (http://file.upi.edu/Direktori/FPBS/JUR._PEND.BAHASA_JERMAN/19800210 2005011-PEPEN_PERMANA/Artikel/PEPENPERMANA-Artikel-Elearning.pdf)

https://ojs.stkippgri-lubuklinggau.ac.id/index.php/JPM 
JURNAL CEMERLANG: Pengabdian pada Masyarakat ISSN 2654-4741

Vol. 1, No. 1, 2018, $58-70$

DOI: https://doi.org/10.31540/jpm.v1i1.159

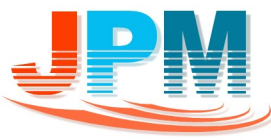

Waryanto, Nur Hadi. (2006) Online Learning Sebagai Salah Satu Inovasi Pembelajaran. Pythagoras Jurnal Matematika dan Pendidikan Matematika, 2 (Des), 10-23.

Wicaksono, Vicky Dwi dan Rachmadyanti, Putri. (2017). Pembelajaran Blended Learning Melalui Google Classroom Di Sekolah Dasar. Prosiding Seminar Nasional Pendidikan PGSD UMS \& HDPGSDI Wilayah Jawa.

Wikipedia. (2017). Google Classroom. (https://en. wikipedia.org/wiki/ Google_Classroom). (https://edu.google.com/intl/id_ALL/?modal_active=none) 